\title{
Coevolution of Poisonous Plants and Large Herbivores on Rangelands
}

\author{
W. A. LAYCOCK
}

Highlight: Early literature generally described toxic plant substances as waste products. However, more recent publications in entomology, plant biochemistry, and other fields suggest that toxic secondary compounds in plants may be defense systems against insects and other herbivores. The pertinence of these discussions to range management is the subject of this paper. If plant poisons have evolved as defense mechanisms, various ways that they might function include: (1) extreme toxicity; (2) poisonous properties linked with palatability; and (3) aversive conditioning, i.e., animals "learn" that a plant will make them ill and avoid that plant. All could reduce consumption of poisonous plants by herbivores, thus making the plants more competitive in natural communities. If plant poisons are defense mechanisms, it would be logical to assume that coevolution has occurred in herbivores to prevent their being poisoned by plants. Some of the possible evolutionary adaptations in large herbivores include: (1) a generalized diet that reduces the probability of eating a toxic amount of any one species; (2) ability to detect and avoid poisonous plants; and (3) ability to detoxify plant poisons. All appear to operate, at least to a degree, in both domestic and wild herbivores. Ability to detect and to detoxify poisons varies among species and appears to be more prevalent in native animals that coevolved with the vegetation than in domestic animals. Native big-game animals are occasionally poisoned by plants but large losses usually occur in overpopulated or overgrazed areas where nonpoisonous species have been depleted.

Traditional range and animal management literature on poisonous plants has dealt largely with: (1) identification of the plants causing livestock losses; (2) identification of the poisonous compounds in the plants; (3) definition of the clinical signs of poisoning in animals; and (4) development of management practices to minimize or avoid losses. The evolutionary history of poisonous plants, the toxic compounds in the plants, or the animals that graze these plants has received little attention.

Hypotheses on evolution of poisonous plants or poisonous compounds have been published in other fields (e.g., entomology, plant biochemistry, and population ecology) but many publications are in outlets not familiar to range ecologists. One objective of this paper is to bring together some of the diverse literature concerning coevolution of poisonous plants and grazing animals. Information from other fields is presented to illustrate specific points, but

\footnotetext{
The author is range scientist. Science and Education Administration-Federal Research, United States Department of Agriculture, Colorado State University, Fort Collins 80523

This article is the result of cooperative investigations of the Science and Education Administration-Federal Research. United States Department of Agriculture and Colorado State University Experiment Station. Scientific Series Paper No. 2330. Manuscript received March 30, 1978.
}

"facts" about the evolutionary processes generally are missing. A second objective of the paper is to stimulate thought and discussion about the role of poisonous plants on rangelands.

The two main questions that will be addressed are: (1) Have poisonous compounds in plants evolved as defense mechanisms against herbivores? and (2) Have herbivores coevolved to cope with plant poisons?

\section{Are Poisons Defense Mechanisms against Herbivores?}

Not much information exists to answer this question and the subject has been almost completely ignored in range management literature. However, in entomology and plant biochemistry, the role of toxic secondary substances in plants has been a subject of debate for many years. Much of the early literature considered these compounds as waste products or as having unknown functions. In the introduction to his book "Poisonous Plants of the United States," Meunscher (1958) stated: "Many hypotheses have been advanced to explain the significance of toxic substances produced in plants, as, that they are developed to protect the plants against herbivorous mammals, are waste products, are stages in the processes of metabolism. Of these suggestions, the first appears the least acceptable and the last the most plausible."

Whittaker and Feeny (1971) and Jones (1973) attribute Stahl (1888) as being the first to suggest that poisonous compounds are defense mechanisms against herbivores. This hypothesis has been strongly defended by Janzen (1973), Freeland and Janzen (1974), Rhoades and Cates (1976), Swain (1977), and others. Literature concerning insect herbivores contains many theories and discussions of the possible ways some toxic compounds may function as anti-herbivores defense systems including: alkaloids (McKey 1974), cyanogenic glycosides (Jones 1973), phenolics (Levin 1971), and tannins (Feeny 1970). The effectiveness of these compounds as defense mechanisms is relatively clear. However, "proof" that they evolved for that purpose is impossible.

The reasons advanced to support the defense mechanism theories include: (1) In some plants, concentration of the poisonous compounds is great or the compounds are highly complex structurally (Swain 1977); thus the energy cost of producing and storing them would appear to be too high unless the compounds had some function to increase fitness, such as a defense mechanism against herbivores (Rhoades 
and Cates 1976). (2) The great number of different kinds of poisonous compounds and species of plants containing these poisons appears to be too high for their evolution to be accidental. (3) Few poisonous compounds can be classified, with present knowledge, as either by-products or as compounds essential for plant metabolism. To some, this implies that these compounds serve other functions, such as defense mechanisms against herbivores. (4) Insects and some large herbivores have developed resistance to or ways to detoxify, sequester, or otherwise render ineffective specific plant poisons. This suggest coevolution of the poisonous plants and the herbivores.

\section{How Might Plant Poisons Function as Defense Mechanisms?}

If toxic secondary compounds in plants function as defense mechanisms against herbivores, there are various ways that they might operate. All defense mechanisms proposed are based on the assumption that being poisonous results in a reduction of the amount of plant material removed by herbivores, in turn maintaining the vigor of the plant and making it better able to survive in a natural plant community. Possible ways that poisonous compounds may function include: (1) extreme toxicity; (2) poisonous properties correlated with palatability; and (3) aversive conditioning.

\section{Extreme Toxicity}

Poisonous species might gain a competitive advantage if they were so toxic that consumption by an herbivore resulted in death or lowered fitness, in terms of growth rate or fecundity (Rhoades and Cates 1976). The resulting reduction in consumption would be most effective if the herbivores involved were specialists, i.e., those that feed only on one (or a few closely related) plant species. Many insects are specialists and extreme toxicity in a plant may operate effectively as a defense against them. It seems possible that, for many plant species, poisonous properties have evolved as defense mechanisms against specialist-type insects (Feeny 1975) or against disease-causing organisms (Swain 1977) and the fact that they are poisonous to large herbivores may be accidental.

Most large herbivores are generalists, i.e., they eat a great variety of plants. If a plant species eaten by a generalist kills or makes the animal ill thus reducing food intake, the "advantage" to the poisonous species may or may not accrue. Herbivores that are killed would not only stop feeding on the poisonous plants but also on all other plant species. Thus, the poisonous plants might not gain any competitive advantage in the community or any long-term evolutionary advantage. Freeland (1974) hypothesized that, in the absence of grazing, preferred or palatable food plants "outcompete toxic species" and the toxic species decrease in importance in the plant community, presumably because the nontoxic species put more of their resources into growth instead of defense.

\section{Poisonous Properties Correlated with Palatability}

Poisonous plants that are unpalatable may gain a competitive advantage in the community. However, poisonous plants occur in a wide spectrum of palatability from extremely unpalatable to palatable (Cronin et al. 1978). In addition, palatability is relative because it depends upon the species of animal, the choice of other plants available, and many other factors. Linking poisonous properties to palatability may not be a valid argument in explaining how poisonous properties might work as defense mechanisms because an unpalatable plant does not necessarily need to be poisonous to have a competitive advantage over palatable plants that are readily eaten by herbivores (Bate-Smith 1972). For unpalatability to have operated as an evolutionary factor, it probably has to be linked to aversive conditioning as described below.

\section{Aversive Conditioning}

This phenomenon is also called conditioned taste aversion or learned food aversion. The basic premise is that if an animal consumes a flavored food and subsequently becomes ill, that animal will avoid or drastically reduce consumption of that flavor upon later encounters (Gustavson 1977). The strength of the resulting aversion apparently is directly related to the length of time between consumption and the onset of the illness, the discriminability and novelty of the flavor, and the intensity of the illness.

Taste aversions have been experimentally induced in a wide variety of animals. The sampling of small quantities of novel foods by rats behaviorally enhances an ability to distinguish tastes of and to subsequently avoid food flavors that have made them ill. Aversive stimuli (e.g., X-ray irradiation or injections of lithium chloride) ad ministered as much as 18 hours later can produce conditioned avoidance of the last food consumed by rats (Revunsky and Garcia 1970).

In addition to numerous articles in scientific journals, an entire book has been published on the subject of food selection and aversive conditioning (Barker et al. 1977) and a complete discussion cannot be presented here. Gustavson (1977) reported that aversions have been shown in a great many species of animals and birds, including carnivores (e.g., coyotes, timberwolves), omnivores (e.g., black bears, squirrel monkeys), some herbivores (e.g., rhesus and green monkeys, guinea pigs), birds (e.g., raptors, chickadees), and other diverse forms such as garter snakes, Atlantic cod, and land slugs. Aversive conditioning also has been used in treatment of human problems such as alcoholism (Mottlin 1973), smoking, and overeating (Garb and Stunkard 1974).

A classic example of naturally occurring aversive conditioning involving blue jays ( $C$ vanocitta cristata) and monarch butterflies (Danaus plexippus) was described by Brower (1969). Some larvae of the monarch butterfly feed on milkweed (Asclepias curassavica) and absorb quantities of a bitter and highly poisonous cardiac glycoside. The adult butterflies developing from these larvae retain the glycoside, are distasteful to the blue jays and will make the birds sick if consumed. Conditioned jays then avoid all monarch butterflies on sight, even those whose bodies do not contain the glycoside. However, taste has a place in the aversion because, if driven by hunger, jays will seize the insects, sample small bites and then eat the nontoxic ones and discard the toxic (bitter) ones.

Aversive conditioning has been used in attempts to reduce damage to livestock or crops. Gustavson et al. (1974) have reported that coyotes can be prevented from attacking sheep 
under controlled conditions by feeding them baits of lamb meat, hide and wool laced with lithium chloride, a fast acting, powerful gastrointestinal poison. However, another study with mice and chickens has raised questions about the effectiveness of lithium chloride in dead baits in averting coyotes from attacking and killing live prey (Conover et al. 1977). Some field trials using lamb baits laced with lithium chloride have been conducted (Ellens et al. 1977; Gustavson 1977), with some reported success. Sterner and Shumake (In press) have outlined some of the limitations of published aversive conditioning field trials. Adequate controls are difficult in such studies and Dorrance and Gilbert (1977) outlined the requirements for field-scale tests of aversive conditioning. Research has been conducted to determine the effectiveness of aversive conditioning to prevent black bear damage to bee yards (Gilbert and Roy 1975) and to prevent damage to crops by birds (Shumake et al. 1977, Schaefer et al. 1977).

A discussion of the possible role of aversive conditioning in preventing large herbivores from consuming poisonous plants will be presented in the next section.

\section{How Have Animals Evolved to Cope with Poisonous Plants?}

If plants have developed poisonous properties as defense mechanisms against herbivores, animals should have coevolved either to avoid the plants or to detoxify or otherwise avoid being poisoned by the poisonous compounds. Much of the literature dealing with the coevolution theory related to poisonous plants has been confined to insects (Ehrlich and Raven 1965; Fraenkel 1969; Feeny 1975; Jones 1973; Whittaker and Feeny 1971). As mentioned above, many poisonous secondary plant compounds may have evolved as defense mechanisms against specific insects. Some of the possible mechanisms by which large herbivores could be demonstrating evolutionary adaptations to poisonous plants include: (1) a generalized diet; (2) ability to detect and avoid poisonous plants; (3) ability to detoxify plant poisons when ingested.

\section{Generalized Diet}

Most large herbivores are generalists. One advantage of a varied diet would be to reduce the probability of eating a toxic amount of any one poisonous species. Another proposed advantage is that a variety of foods would be more likely to give the animal a balanced nutrient intake. This has been referred to as "nutritional wisdom," i.e., animals possess an instinct which enables them to select a diet best suited to their nutrient requirements. Reviews of studies that either support or refute this concept were published by Marten (1970), Westoby (1974), and Zahorik and Houpt (1977). Ivins (1955) suggested that until the theory of nutritional wisdom is conclusively confirmed or disproved, the marked preference animals show for particular herbage species is a factor which must be respected. He cautioned that it is possible to carry this view too far because livestock are frequently poisoned by plants and concluded that this "cannot be regarded as an inherent desire on the part of the animal to commit suicide."

\section{Ability to Detect and Avoid Poisonous Plants}

The ability to detect poisonous plants and thus avoid consumption certainly must be considered as adaptive. This ability is one aspect of the complex behavior pattern of animals about which we have little information. Native animals that coevolved with the vegetation should be able to avoid native poisonous plants better than domestic animals that have been moved from their native habitat or developed in agricultural systems. Many examples of this exist in the literature. Arnold and Hill (1972) observed that, in western Australia, sheep preferentially eat plants of Gastrolobium and Oxylobium, whose monofluoroacetic acid content is lethal, while native kangaroos avoid these plants. Dixon (1934) found that, although plants poisonous to livestock (such as azalea [Azalea spp.] and larkspur [Delphinium spp.]) were abundant on summer range in California, mule deer did not graze these species.

Domestic livestock apparently also have the ability to detect poisonous plants, at least in some circumstances. Somc studics dealing with the preference of livestock for nontoxic or less toxic species, strains, or individuals within a population are summarized in Table 1 . All of these plants have caused livestock losses in other situations. How the animals were able to select and avoid the most poisonous plants is not known but these studies confirm that domestic livestock do have the ability to detect some poisonous compounds in some plants.

Little is known about the variability in concentration of toxic compounds in natural populations of plants and the

Table 1. Examples of studies in which grazing animals exhibited distinct preferences for nontoxic or less toxic plant species, individual plants, or strains.

\begin{tabular}{llll}
\hline \hline Plant species & Poisonous compound & Animal & Reference \\
\hline $\begin{array}{l}\text { Blue lupine } \\
\text { (Lupinus angustifolius) }\end{array}$ & Alkaloid & Sheep & Arnold and Hill 1972 \\
$\begin{array}{l}\text { Reed canarygrass } \\
\text { (Phalaris arundinacea) }\end{array}$ & Alkaloid & Sheep & $\begin{array}{l}\text { Simons and Marten, 1971 } \\
\text { Williams, et al. 1971 }\end{array}$ \\
$\begin{array}{l}\text { Crotalaria } \\
\text { (Crotalaria spectabilis) }\end{array}$ & Alkaloid & Cattle & Becker, et al. 1935 \\
$\begin{array}{l}\text { Bracken fern } \\
\text { (Pteridium aquilinum) }\end{array}$ & Cyanogenic glycoside & Sheep and deer & Cooper-Driver and Swain 1976 \\
$\begin{array}{l}\text { Sorghum (S. bicolor) and } \\
\text { Sudangrass hybrids }(S . \text { sudanense })\end{array}$ & Cyanogenic glycoside & Cattle and sheep & Rabas, et al. 1970 \\
$\begin{array}{l}\text { Sericea lespedeza } \\
\text { Lespedeza (uneata })\end{array}$ & Tannin & Cattle & Wilkins, et al. 1953
\end{tabular}


interrelationship of toxicity with preference by herbivores. Cooper-Driver and Swain (1976) found that, in most populations of bracken fern (Pteridium aquilinum), $96 \%$ of the individual plants were cyanogenic, while in a few populations $98 \%$ of the plants were acyanogenic. Studies of this type are needed for the major poisonous plant species on rangelands.

\section{How Do Animals Detect and Avoid Poisonous Plants?}

Generally, when animals avoid eating poisonous plants, it is assumed that the poisonous compounds are detectable to animals and thus are related to palatability. While all the senses play some role in food selection (Arnold 1964; Krueger et al. 1974), taste is one of the most important aspects of palatability (Arnold and Hill 1972). Kare and Ficken (1963) stated: "One should consider function of taste in different animals, since it is on this aspect that natural selection is acting... It is reasonable to ascribe to it a role in the regulation of ingestion of nutrients and possibly the avoidance of toxic substances."

Many studies have been made on the reasons for palatability of plants and the preferences shown by large herbivores, but no universal relationships between chemical properties and palatability have been found $(\Lambda$ rnold and Hill 1972). Sugar or sweet flavors have been shown to be preferred by many animals in numerous studies. Astringency apparently deters consumption of some herbage containing tannins (Swain 1977). Bitterness is generally repellant to most animals (Bate-Smith 1972). Bitterness is a property of many substances, but alkaloids and cyanogenic glycosides are universally bitter. Bate-Smith (1972) stated: "that these happen to be extremely toxic is incidental-it is their bitterness which is a repellant rather than the fact that they are deadly." In contrast, Garcia and Hankins (1974) contended that: "natural aversions to bitter substances have been acquired by a wide variety of species through natural selection." Thus in their opinion, rejection of bitter is a species behavioral trait involving the evolution of bitter sensors and the motor capacity to reject the substance sensed. Sometime in evolutionary history, survival was enhanced for genotypes of herbivores that rejected bittertasting plants. However, some toxic plants are not bitter, and some bitter plants are not toxic. Thus, a second behavioral trait may have also evolved, i.e., the ability to exclude from the diet toxic plants that are not bitter and the inclusion of bitter plants that are not toxic. Most range managers on western range will recognize plants that fit the latter category. One of the best examples may be bitterbrush (Purshia tridentata), which is nontoxic and highly palatable to sheep, cattle, and deer, but which tastes bitter to humans.

Taste aversion has been demonstrated experimentally in a wide variety of animals but little evidence exists concerning its existence in large herbivores, especially ruminants. Leopold (1948) stated that mammals have highly developed senses of taste and smell and thus avoid poisonous plants through the educational effect of unpleasant individual experiences, i.e., through what is now called aversive conditioning. Zahorik and Houpt (1977) reported a limited trial with cattle in which an aversion to a single food was created by introducing lithium chloride into the rumen immediately after feeding. Kennedy and Baldwin (1972) described the lack of aversive conditioning in pigs. When given a choice between water and sugar solutions, the pigs drank large volumes of the sweet solutions and became ill. However, the animals subsequently failed to avoid the sugar solution. There are also many examples, in field situations, of animals repeatedly eating poisonous plants even though they were made ill from the previous episodes. The reason for the lack of learned aversion in these cases probably is the generalized nature of the diet and the continual grazing behavior of most large herbivores. If an animal eats a poisonous species in a mix of many species consumed during a period of grazing, taste cues to avoid the poisonous plant in the future probably are masked in the complex mixture of flavors. Zahorik and Houpt (1977) concluded that large herbivores are "capable of learning to avoid food on the basis of unpleasant gastrointestinal consequences, although the available evidence does not suggest that this ability is very frequently utilized." Aversive conditioning obviously would not operate with respect to cumulative or very slowacting poisonous compounds. Carefully controlled studies are needed to determine if aversive conditioning does operate in large herbivores under both experimental and natural grazing conditions.

Sampling and cautious ingestion of new foods may also be an adaptive mechanism to avoid being poisoned. This feeding strategy would enhance and work in conjunction with taste aversions in two ways: flavor cues would be more discriminable rather than being lost in a complex mixture of flavors and only sub-lethal quantities of food would be consumed so that the reaction would be one of illness rather than death. Freeland and Janzen (1974) hypothesized that, even if herbivores are capable of detoxifying and eliminating toxic secondary compounds, they would still be forced to consume a variety of plant foods, treat new food with caution, ingest small amounts on the first encounter, and to sample food continuously. The sampling behavior of animals placed in a new vegetation type has been observed by Nichol (1938) for deer and by Krueger (1970) for sheep.

\section{Ability to Detoxify Plant Poisons}

The ability to detoxify plant poisons should be one result of coevolution of herbivores and plants containing toxic secondary compounds. Detoxification is used here as a broad term including metabolic detoxification or any other process that inactivates or renders the toxic compound ineffective. There are numerous publications dealing with species of insects that are specialists on only one plant species that contains toxic secondary compounds (Rothschild 1972). Many of these insects apparently have coevolved to be able to detoxify or sequester the poisons and, in some cases, use these poisonous compounds as "labels" by which they recognize and find their food (Fraenkel 1969).

The ability to detoxify plant poisons also exists for large herbivores. For a given poisonous compound, this ability varies with different animal species. Sheep can eat a larger percentage of their body weight of larkspur (Delphinium spp.) without damage than can cattle (James and Johnson 1976), indicating either differential tolerance or ability to detoxify. Cattle and horses are poisoned by tansy ragwort (Senecio jacobaea) but sheep and goats are immune (Cheeke 1977). In this case the pyrrolizidine alkaloids in the plant are relatively nontoxic, but they are converted to toxic pyrroles in the liver. The resistance of sheep apparently is due to the low rate of liver conversion of alkaloid to pyrrole. 
Black-tailed deer are also immune to poisoning by tansy ragwort (Dean and Winward 1974).

The digestive system is where much detoxification takes place, although microsomal enzymes in the liver or kidneys may also play a role in detoxification of some poisons (Freeland and Janzen 1974). In cases where detoxification of poisonous compounds takes place in the rumen, it is accomplished by the rumen microflora. However, various nonruminant animals such as the kangaroo, hippopotamus, and sloth also have forestomachs in which microbial fermentation takes place (McBee 1971). Moir (1968) summarized the advantages of the presence of such a microflora-"a bacterial population in the stomach offers possibilities of colonizing other plant environments normally dangerous to mammals. If movement into these environments is gradual, some portion of the bacteria population quickly adapts to, and metabolizes, toxic substances to harmless substances...."

Evidence exists that, for at least some poisonous compounds, eating sub-lethal amounts for a period of time enables the rumen microflora to change and thus increase their ability to detoxify the poison. Animals can then eat amounts that would have been lethal earlier. Examples of this in sheep were cited by James et al. (1967) for oxalate in (Halogeton glomeratus in Utah and by Dodson (1959) for oxalate in Oxalis cernua in Australia. Deer that have eaten Douglas fir needles can consume diets of up to $50 \%$ of this species, while rumen function of inexperienced deer is severely inhibited by the digestion inhibitors in this amount of needles (Oh et al. 1967). When detoxification takes place by microsomal enzyme activity in the liver or elsewhere in the body, the amount of toxic material eaten can be gradually increased as the capacity of the detoxification system increases (Freeland and Janzen 1974). Langan and Smith (1970) found that sheep that have had experience with small amounts of pyrrolizidine alkaloids can degrade them, while inexperienced sheep cannot.

Some poisonous compounds have a cumulative effect, and acquired tolerance resulting from small doses would not occur. Plants containing such compounds include bracken fern, rubberweed (Hymenoxy's spp.), and orange sneezeweed (Helenium hoopesii) (U.S. Department of Agriculture 1968).

Native animals that coevolved with the plant community should be able to detoxify poisonous compounds better than domestic livestock. In general this seems to be true. Although native big-game animals avoid some poisonous species, they apparently can eat others without serious affects. Stoddart and Rasmussen (1945) stated that, in Utah, "a number of plants poisonous to livestock are eaten in large quantities by (mule) deer without harm. These include death camas, low larkspur, chokecherry, and others." Similar statements have been made about other wild animals eating large quantities of poisonous plants without damage, including pronghorn antelope (Antilocapra americana) (Beuchner 1950; Hoover et al. 1959); white-tailed deer (Odocoileus virginianus) (Forbes and Bechdel 1931; Massey 1967); elk (Cervus canadensis) (Massey 1967); ground squirrels (Citellus spp.) (Honess and Winter 1956); and giraffes (Giraffa camelopardis) (Verdcourt and Trump 1969). In western Australia, species of Gastrolobium and Oxylobium, contain large quantities of monofluoroacetic acid and are extremely poisonous to livestock. Oliver et al. (1977) studied susceptibility of native mammals, red kanga- roo (Megaleia rufa), western grey kangaroo (Macropus fulinginosus ocydromus), bush rat (Rattus fuscipes), and brushtailed opossum (Trichosurus vulpecula), to compound 1080 , which is a similar fluroacetate compound. Western Australian populations had a substantially higher tolerance to this poison than was found in eastern populations of the same species. Everist (1974) stated that native animals and birds can eat Oxylobium without ill effect, but the viscera of such animals has been reported to kill dogs and cats.

While it is generally true that game animals are not killed by poisonous plants, numerous examples of losses do exist for almost all big-game animals native to North America. This indicates that the abilitics to avoid or to detoxify poisons are not infallible. These abilities may vary with individuals, because isolated animals have been reported to have been killed by a wide variety of native poisonous plants including: an antelope killed by chokecherry (Ogilvie 1955), a moose (Alces alces) killed by selenium poisoning (Honess and Winter 1956), and a white-tailed deer killed by Solanum spp. (Case and Murphy 1962).

Relatively large losses have also occurred with some biggame animals on areas either overpopulated by the game animals or overgrazed by livestock and game animals. In such cases, the more palatable plants become depleted, forcing animals to consume lethal quantities of normally unpalatable poisonous plants. Examples of large losses include: antelope killed by tarbush (Flourensia cernua) (Hailey et al. 1966); elk killed by locoweed (Astragalus spp. and Oxytropis spp.) (Adcock and Keiss 1969); both whitetailed deer (Case and Murphy 1962) and black-tailed deer (Odocoileus hemionus columbianus)' killed by tannin poisoning from acorns; black-tailed deer killed by narrowleaved milkweed (Asclepias mexicana) ${ }^{2}$; and Sika deer (2Cervus nippon) killed by the pine oil in pine twigs and needles (Hayes and Shotts 1958). In Australia, Everist (1974) reported evidence that koalas (Phascolarctos cinereus) were killed after feeding on fresh young regrowth of mannagum (Eucalyptus viminalis) after bush fires or periods of very vigorous growth. The leaves of this tree are believed to contain a cyanogenic glycoside.

The evidence indicates that large native herbivores indeed are more resistant to plant poisoning than are domestic livestock. Such resistance should not extend to plants introduced by man, but the only example of poisoning of a native animal by an exotic plant was that of a white-tailed deer killed by cyanide poisoning from sorghum consumption (Case and Murphy 1962). Perhaps the tendency for a generalized diet is more highly developed for native animals than for livestock and this generally prevents ingestion of lethal doses of even exotic poisonous plants.

An exotic plant that would be expected to cause losses of native animals on rangelands is Halogeton glomerata, a native of Asia but now widely distributed in the intermountain areas of North America. This species should be palatable to antelope and toxic if eaten in large amounts. No published records of utilization by antelope were found, but unpublished observations in western $\mathrm{Utah}^{2}$ indicated some use of halogeton by antelope but no mortality. However, native rodents in desert shrub communities in southern Idaho were found to make heavy use of halogeton leaves and

IPersonal communication. Oscar A. Brunetti. California Dept of Fish and Game Sacramento, Calif.

2Personal communication. Arthur D. Smith. Utah State Univ.. Logan. Utah. 
seeds during spring and early summer with no apparent ill cffect (Johnson 1961).

In another theoretical consideration of the effect of poisonous plants on native animal populations, Freeland (1974) hypothesized that cyclic changes in vole (Microtus spp.) populations may be affected by toxic plants. As vole populations increase, availability of preferred, nontoxic food would decrease. This would force "consumption of toxic foods and a consequent reduction in vole viability, leading to a population 'crash'."

\section{Other Evolutionary Considerations}

\section{Ecological and Successionary Considerations}

Rhoades and Cates (1976) postulated that compounds they classified as plant toxins (e.g. alkaloids, cyanogenic glycosides, and oxalates) are most commonly found in ephemeral leaf tissues (annuals, young leaves of herbaceous perennials). Those classified as digestibility-reducing compounds (e.g. tannins) are found in highest concentrations in older leaves of perennials, especially shrubs and trees. The plant toxins usually are relatively low in concentration (often less than $2 \%$ of dry weight) while the digestibilityreducing compounds may make up more than $60 \%$ of the dry weight of tissues in which they occur. Levin (1976) found the incidence of alkaloids to be nearly twice as great in annuals as in perennials on a worldwide basis.

Rhoades and Cates (1976) suggested the following reasons for the differences in types of poisonous compounds in different types of plants: (1) Ephemeral plants and tissue are only present for a short period, are grazed mainly by generalists, and thus escape from those herbivores in space and time. Cates and Orians (1975) stated that these types of species are most prevalent in successional communities, but this would be true mainly where the final or "climax" community was dominated by woody plants and not on grasslands or most other rangelands. (2) Defenses of perennial plants and tissues must be more concentrated because these plants are available to herbivores, mainly specialists, most of the time. The digestibility-reducing compounds fit this pattern and are much more "costly" for the plants to produce and store.

Feeny (1976) proposed a similar explanation and theorized that "apparent" (easy to find) plants such as woody perennials utilize "quantitative" chemical defenses and that the leaves of such plants are "plainly poor food for most potential enemies." "Unapparent" (hard to find) plants, such as annuals and ephemeral perennials, utilize "qualitative" chemical defenses which have a low metabolic "cost" to the plant.

\section{Effects of Herbivores on Poisonous Plants}

The role of herbivorous insects in the population dynamics of plants, including toxic plants, was reviewed by Harris (1972). The effects of grazing by large herbivores is the subject of a large amount of range management literature. With overgrazing, relatively palatable poisonous plants probably decline in abundance along with other palatable species. However, the effects of grazing on unpalatable poisonous plants often are indirect. With heavy grazing, the more palatable species in the community are grazed prefer- entially, reducing competition, and allowing the unpalatable poisonous plants to increase.

The direct effect of foliage removal on growth and toxic properties of poisonous plants has received little study. Janzen (1976) found that artificial defoliation of the Kentucky coffee tree (Gymnocladus dioicus) reduced seed size and the concentration of poisonous compounds in the seeds. Janzen (1976) speculated that, because this tree is normally not fed upon by insects or other herbivores, it not physiologically well buffered against such damage. However, clipping also resulted in a significant reduction in both plant growth and concentration of total alkaloids in duncecap larkspur (Delphinium occidentale), a poisonous plant which is quite palatable to livestock (Laycock 1975). From the limited information available, it appears that both palatable and unpalatable poisonous plant species react similarly to defoliation. Research is needed to determine the effects of foliage removal on major poisonous plant species on rangelands.

Herbicides may increase alkaloid concentration, at least for some species. Silvex (2,4,5-TP) and (2,4,5-T) treatments significantly increased total alkaloid content of tall larkspur (Delphinium barbeyi) (Williams and Cronin 1963) and duncecap larkspur, while 2,4,5-T increased alkaloid content of western false hellebore (Veratrum californicum) (Williams and Cronin 1966). Tall larkspur becomes more palatable to cattle following herbicide applications (Cronin and Nielsen 1972) and this, coupled with the increased alkaloid content, makes grazing of herbicide-treated stands of larkspur extremely hazardous (Williams and Cronin 1966).

\section{Conclusions}

Circumstantial evidence indicates that the evolutionary mechanisms proposed for poisonous plants to minimize consumption by herbivores may operate under certain circumstances. However, because of the wide range of ecological niches filled by poisonous plants (Cronin et al. 1978) the effectiveness of these adaptations varies considerably. Being poisonous in itself usually is not automatically "advantageous" to a plant. Poisonous plants occur over a wide range of palatabilities and palatability varies with species of animals. Thus, being unpalatable as well as poisonous does not always protect a plant from use by all herbivores. Some insects feed on only one species of poisonous plants and apparently use the poisonous compounds as "labels" by which they find their food (Fraenkel 1969).

Evolutionary adaptations proposed for animals to cope with poisonous plants also seem to be effective only in some situations. A generalized diet often prevents ingestion of a toxic amount of any given poisonous plant but not always. All large herbivores seem to have the ability to detect and avoid poisonous plants under some circumstances. They also have the ability to detoxify or otherwise render ineffective a certain level of some ingested poisons but poisoning does occur even in native wild herbivores that evolved with the vegetation.

Aversive conditioning appears to be a coevolutionary adaptation which may protect both the plant and the animal However, this adaptation may operate only at a very low level for large herbivores. Aversive conditioning in the past evolutionary history of both plants and animals may be at 
least partially responsible for the lack of palatability (or the ability of the animal to detect and avoid the plants) being linked with poisonous properties for some plants. Aversive conditioning might also be one factor involved in the evolution of a generalized diet in most range herbivores.

The lack of overwhelming evidence that being poisonous is always advantageous to plants or that herbivores have developed mechanisms that always operate to prevent poisoning by these plants indicates that coevolution has taken place. Thus neither the poisonous plant nor the animal has any clear cut "advantage." Jones (1973), in discussing coevolution of plants and insects, proposed a "leap-frogging" of evolutionary development of toxic compounds in plants and the adaptations of insects to cope with these toxins. The same should hold true in the evolution of large herbivores.

Studies are needed to increase our knowledge about the possible mechanisms of coevolution of poisonous plants and animals. This understanding should help range managers better understand animal behavior where poisonous plants are involved, which, in turn, should lead to better management of both the animals and the range to minimize losses caused by poisonous plants.

Other studies needed to clarify the interrelationships between poisonous plants and herbivores include:

1) Determination of the presence or absence of and intensity of conditioned taste aversion as a factor in food selection by large herbivores, especially ruminants.

2. Controlled feeding trials with both native and introduced poisonous plant species to determine and/or quantify the ability of native big-game animals to detoxify poisonous compounds.

3. Determination of the processes and sites of detoxification of poisonous compounds within the bodies of all classes of herbivores.

4. Determination of the variability in concentration of toxic compounds in natural populations of poisonous plants and the interrelationships between level of toxicity and palatability.

5. Controlled clipping studies on major poisonous plant species to determine effects of foliage removal on growth, vigor, content of toxic compounds, and palatability to grazing animals. Competitive ability of poisonous species, both with and without foliage removal, should be determincd as a part of these studies.

\section{Literature Cited}

Adcock, L. J., and R. E. Keiss. 1969. Locoism in elk: a disease resembling cerebral pseudolipidosis. Bull. Wildl. Dis. Ass. 5:121-124.

Arnold, G. W. 1964. Some principles in the investigation of selective grazing. Proc. Austr. Soc. Anim. Prod. 5:258-271.

Arnold, G. W., and J. L. Hill. 1972. Chemical factors affecting selection of food plants by ruminants. In: Phytochemical ecology, J. B. Harborne (ed.) Proc. Phytochem. Soc. 8:71-101. Academic Press, New York.

Barker, L. M., M. R. Best, and M. Domjan (eds.). 1977. Learning Mechanisms in Food Selection. Baylor University Press $632 \mathrm{p}$.

Bate-Smith, E. C. 1972. Attractants and repellents in higher animals. In: Phytochemical ecology, J. B. Harborne (ed.) Proc. Phytochem. Soc. 8:45-56. Academic Press, New York.

Becker, R. B., W. M. Neal, P. T. D. Arnold, and A. L. Shealy. 1935. $\Lambda$ study of the palatability and possible toxicity of eleven species of crotalaria, especially of C. spectabilis. J. Agr. Res. 50:911-922.

Brower, L. P. 1969. Ecological chemistry. Sci. Amer. 220(2):22-29.

Buechner, H. K. 1950. Life history, ecology, and range use of the pronghorn antelope in Trans-Pecos Texas. Amer. Midland Natur. 43:257-354.

Case A. A., and D. A. Murphy. 1962. Poisoning in whitc-tailed deer. Proc. Ist National White-Tailed Deer Symp. p. 128-131.
Cates, R. G., and G. H. Orians. 1975. Successional status and the palatability of plants to generalized herbivores. Ecology 56:410-418.

Cheeke, Peter R. 1977. What makes tansy tick? Anim. Nutr. \& Health 32:15-16.

Conover, M. R., J. G. Francik, and D. E. Miller. 1977. An experimental evaluation of aversive conditioning for controlling coyote predation. J. Wildl. Manage. 41:775-779.

Cooper-Driver, G. A., and T. Swain. 1976. Cyanogenic polymorphism in bracken in relation to herbivore predation. Nature 260:604.

Cooper-Driver, G. A., S. Finch, T. Swain, and E. Bernays. 1977. Seasonal variation in secondary plant compounds in relation to the palatability of Pteridium aquilinum. Biochem. Syst. Ecol. 5:177-185.

Cronin, E. H., P. R. Ogden, J. A. Young, and W. A. Laycock. 1978. The ecological niche of poisonous plants in range communities. J. Range Manage. 31:328-334.

Cronin, E. H., and D. Nielsen. 1972. Controlling tall larkspur on snowdrift areas in the subalpine zone. J. Range Manage. 25:213-216.

Dean, R. E., and A. H. Winward. 1974. An investigation into the possibility of tansy ragwort poisoning of black-tailed deer. J. Wildl. Dis. 10:166-169.

Dixon, J. S. 1934. A study of the life history and food habits of mule deer in California, Part 2. Food habits. California Fish and Game 20:315-354.

Dodson, M. E. 1959. Oxalate ingestion studies in sheep. Australia Vet. J. $35: 225-233$.

Donnelly, E. D. 1954. Some factors that affect palatability in sericea lespedeza, L. cuneata. Agron. J. 46:96-97.

Dorrance, M. J., and B. K. Gilbert. 1977. Considerations in the application of aversive conditioning. In: Test methods for vertebrate pest control and management materials. Jackson, W. B. and R. E. Marsh (eds.) Amer. Soc. for Testing and Materials, Spec. Tech. Pub. 625:136-144.

Ehrlich, P. R., and P. H. Raven. 1965. Butterflies and plants: a study in coevolution. Evolution 18:586-608.

Ellens, S. R., S. M. Catalano, and S. A. Schechinger. 1977. Conditioned taste aversion: a field application to coyote predation on sheep. Behav. Biol. 20:91-95.

Everist, Selwyn L. 1974. Poisonous Plants of Australia. Angus and Robertson. 684 p.

Feeny, Paul. 1970. Seasonal changes in oak leaf tannins and nutrients as a cause of spring feeding by winter moth caterpillars. Ecology 51:564581

Feeny, Paul. 1975. Biochemical coevolution between plants and their insect herbivores. In: Coevolution of Animals and Plants. Gilbert, L. E. and P. H. Raven (eds.), University Texas Press, Austin. p. 3-19.

Feeny, Paul. 1976. Plant apparency and chemical defense. Recent Advances in Phytochemistry 10:1-10.

Forbes, E. B., and S. I. Bechdel. 1931. Mountain laurel and rhododendron as foods for the whitc-tailed decr. Ecology 12:323-333.

Fraenkel, G. S. 1969. The raison d'etre of secondary plant substances. Sci. 129:1466-1470.

Freeland, W. J. 1974. Vole cycles-another hypothesis. Amer. Natur. 108:238-245

Freeland, W. J., and D. H. Janzen. 1974. Strategies in herbivory by mammals. Amer. Natur. 108:269-289.

Garb, J. L., and A. J. Stunkard. 1974. Taste aversions in man. Amer. J. Psychiat. 131:1204-1207.

Garcia, John, and W. G. Hankins. 1974. The evolution of bitter and the acquisition of toxiphobia. In: Fifth International Symposium on Olfaction and Taste. D. Denton (ed.), Melbourne, Australia. p. 1-12.

Gilbert, B. K., and L. D. Roy. 1975. Prevention of black bear damage to beeyards using aversive conditioning. In: Proc. 1974 Predator Symposium, R. L. Phillips and C. J. Jonkel (eds.), University Montana, Missoula p. 93-102.

Gustavson, Carl R. 1977. Comparative and field aspects of learned food aversions. In: Learning Mechanisms in Food Selection, L. M. Barker, M. R. Best, and M. Domjan (eds.), Baylor University Press. p. 23-43.

Gustavson, C. R., J. Garcia, W. G. Hankins, and K. W. Rusinak. 1974. Coyote predation control by aversive conditioning. Sci. 184:581-583.

Hailey, T. L., J. W. Thomas, R. M. Robinson. 1966. Pronghorn die-off in Trans-Pecos, Texas. J. Wildl. Manage. 30:488-496.

Harris, P. 1972. Insects in the population dynamics of plants. In: Insect plant relationships. H. F. vanEmden (ed.), Symposia of the Royal Entomological Society of London 6:201-209.

Hayes, F. A., and E. B. Schotts. 1958. Pine-oil poisoning in Sika deer Southeast. Vet. 10:34-39.

Honess, R. F., and K. B. Winter. 1956. Discascs of wildlife in Wyoming. Wyoming Game and Fish Comm. Bull. 9, 63 p.

Hoover, R. L., C. E. Till, and S. Ogilvie. 1959. The antelope of Colorado: 
a research and management study. Colorado Dep. Fish and Game Tech. Bull. $4.110 \mathrm{p}$.

Ivins, J. D. 1955. The palatability of herbage. Herb. Abstr. 25:75-79.

James, Lynn F., and A. E. Johnson. 1976. Some major plant toxicities of the Western United States. J. Range Manage. 29:356-363.

James, Lynn F., Joseph C. Street, and John E. Butcher. 1967. In vitro degradation of oxalate and of cellulose by rumen ingesta from sheep fed Halogeton glomeratus. J. Anim. Sci. 26:1438.

Janzen, D. H. 1973. Community structure of secondary compounds in plants. Pure and Applied Chem. 34:529-538

Janzen, D. H. 1976. Effect of defoliation on fruit-bearing branches of the Kentucky Coffee Tree, Gvmnocladus dioicus (Leguminosae). Amer. Midland Natur. 95:474-478.

Johnson, Donald R. 1961. The food habits of rodents on rangelands of southern Idaho. Ecology 42:407-410.

Jones, David A. 1973. Co-evolution and cyanogenesis. In: Taxonomy and ecology, V. H. Heywood (ed.), p. 213-242. Academic Press, New York.

Kare, Morley R., and M. S. Ficken. 1963. Comparative studies on sense of taste. In: Proceedings First International Symposium on Olfaction and Taste p. 285-297. Pergammon Press, New York.

Kennedy, J. M., and B. A. Baldwin. 1972. Taste preferences in pigs for nutritive and non-nutritive sweet solutions. Anim. Behav. 20:706-718.

Krueger, W.C. 1970. The relationship of special senses to forage selection. PhD Diss., Utah State Univ., Logan, 87 p.

Krueger, W. C., W. A. Laycock, and D. A. Price. 1974. Relationships of taste, smell, sight, and touch to forage selection. J. Range Manage. $27: 258-262$.

Langan, G. W., and L. W. Smith. 1970. Metabolism of pyrrolizidine alkaloids in ovine rumen. I. Formation of 7 alph-hydroxyl-alphy-methyl-8 alpha-pyrrolizidine from heliotrine and basiocarpine. Australia J. Agr. Res. 21:493-500.

Laycock, W. A. 1975. Alkaloid content of duncecap larkspur after two years of clipping. J. Range Mange. 28:257-259.

Leopold, A. 1948. Game Management. Charles Scribner’s Sons, New York $481 \mathrm{p}$.

Levin, D. A. 1971. Plant phenolics: an ecological perspective. Amer. Natur. 105:157-181.

Levin, D. A. 1976. Alkaloid hearing plants an eco-geographic perspective Amer. Natur. 110:261-284.

Marten, G. C. 1970. Measurement and significance of palatability. In: Proc. of National Conference on Forage Quality Evaluation and Utilization. D1-D55. Nebraska Center for Continuing Education. Lincoln.

Massey, A. B. 1967. Poisonous plants in Virginia. Virginia Polytechnic Inst. Coop. Ext. Serv. Bull. 222, 43 p.

McBee, R. H. 1971. Significance of intestinal microflora in herbivory. Ann. Rev. Ecol. and Systematics. 2:165-176.

McKey, Doyle. 1974. Adaptive patterns in alkaloid physiology. Amer Natur. 108:305-320.

Moir, R. J. 1968. Ruminant digestion and evolution. In: Handbook of Physiology. Alimentary Canal, Vol. 5. Amer. Physiol. Soc. Washington D.C. p. 2673-2694.

Mottlin, J. L. 1973. Drug-induced attenuation of alcohol consumption. A review and evaluation of claimed, potential, or current therapics. Quart. J. Studies on Alcohol 34:444-472.

Muenscher, Walter C. 1958. Poisonous plants of the United States. The Macmillan Co., New York 277 p.

Nichol, A. A. 1938. Experimental feeding of deer. Univ. Arizona Agr. Exp. Sta. Tech. Bull. 85, 39 p.

Ogilvie, S. 1955. Chokecherry toxic to an antelope. J. Mammal. 36:146.
Oh, H. K., T. Sakai, M. B. Jones, and W. M. Longhurst. Effect of various essential oils isolated from Douglas fir needles upon sheep and deer rumen microbial activity. Appl. Microbiol. 15:777-784.

Oliver, A. J., D. R. King, and R. J. Mead. 1977. The evolution of resistance to fluoroacetate intoxication in mammals. Search 8:130-132.

Rabas, D. L., A. R. Schmid, and G. C. Marten. 1970. Relationship of chemical composition and morphological characteristics to palatability in sudangrass and sorghum x sudangrass hybrids. Agron. J. 62:762-763.

Revusky, S. H., and J. Garcia. 1970. Learned associations over long delays. In: The Psychology of Learning and Motivation. G. H. Bower and J. T. Spence (eds.), Academic Press, New York. p. 1-84.

Rhoades, David F., and Rex G. Cates. 1976. Toward a general theory of plant antiherbivore chemistry. In: Biochemical interaction between plants and insects. J. Wallace and R. Mansell (eds.), Recent Advances in Phytochem. 10:168-213.

Rothschild, Miriam. 1972. Some observations on the relationship between plants, toxic insects and birds. In: Phytochemical ecology. J. B. Harborne (ed.), Proc. Phytochem. Soc. 8:1-12. Academic Press, New York.

Schafer, E. W., Jr., R. B. Brunton, and N. F. Lockyer. 1977. Learned aversion in wild birds; a method for testing comparative acute repellency. In: Test methods for vertebrate pest control and management materials. W. B. Jackson and R. E. Marsh (eds), Amer. Soc. for Testing and Materials, Special Tech. Pub 625:186-194.

Shumake, S. A., S. E. Gaddis, E. W.Schafer, Jr. 1977. Behavioral response of Quela to methiocarb (mesurol). Proc. Seventh Bird Control Seminar, Bowling Green State Univ., Bowling Green, Ohio. p. 250-254.

Simons, A. B., and C. G. Marten. 1971. Relationship of indole alkaloids to palatability of Phalaris arundinacea L. Agron. J. 63:915-919.

Stahl, E. 1888. Pflanzen and Schnecken. Eine biologische Studie uber die Schutzmittel der Pflanzen gegen Schneckenfrass. Jena. Z. Med. Natur. 22:557-684. (cited by Jones, 1973).

Sterner, R. T., and S. A. Shumake. In Press. Bait-induced prey aversions in predators: some methodological issues. Behav. Biol.

Stoddart, L. A., and D. I. Rasmussen. 1945. Deer management and range livestock production. Utah Agr. Exp. Sta. Circ. 121, 17 p.

Swain, T. 1977. Secondary compounds as protective agents. Ann. Rev. Plant Physiol. 28:479-500.

U.S. Department of Agriculture. 1968. 22 plants poisonous to livestock in the western states. U.S. Dep. Agr., Agr. Info. Bull. No. 327, 64 p.

Verdcort, Bernard, and E. C. Trump. 1969. Common poisonous plants of East $\Lambda$ frica. Collins, St. James Place. $254 \mathrm{p}$.

Westoby, Mark. 1974. An analysis of diet selection by large generalist herbivores. Amer. Natur. 108:290-304.

Whittaker, R. H., and P. P. Feeny. 1971. Allelochemics: chemical interactions between species. Sci. 171:757-770.

Wilkins, H. L., R. P. Bates, P. R. Henson, I. L. Lindahl, and R. E. Davis. 1953. Tannin and palatability in sericea lespedeza, $L$. cuneata. Agron. J. 45:335-336.

Williams, M., R. Barnes, and J. Cassady. 1971. Characterization of alkaloids in palatable and unpalatable clones of Phalaris arundinacea $\mathrm{L}$. Crop Sci. 11:213-217.

Williams, M. Coburn, and E. H. Cronin. 1963. Effect of silvex and 2,4,5-T on alkaloid content of tall larkspur. Weeds 11:317-319.

Williams, M. Coburn, and E. H. Cronin. 1966. Five poisonous range weeds -when and why they are dangerous. J. Range Manage. 19:274-279.

Zahorik, Donna M., and Katherine A. Houpt. 1977. The concept of nutritional wisdom: applicability of laboratory learning models to large herbivores. In: Learning Mechanisms in Food Selection. L. M. Barker, M. R. Best, and M. Domjan (eds.), Baylor University Press. p. 45-46. 